\title{
PHYSICOCHEMICAL DIFFERENCES BETWEEN COOKING AND PASTEURIZED BUTTER SOLD IN ALEXANDRIA CITY
}

\author{
HANAA H.A. EL-MOSSALAMI* and Y.A. ABDEL-HAKEIM** \\ *,** Dep. of Food Hygiene, Animal Health Research Institute / Alex. Branch. \\ Email: elmoslamyh@yahoo.com
}

\section{ABSTRACT}

Received at: 30/12/2014

Accepted: 12/2/2014
Fifty random samples of cooking and pasteurized cow butter (25 samples each) were collected from different markets in Alexandria, city. Samples were examined for organoleptic and physicochemical characters. Sensory evaluation revealed that $10(40 \%) ; 9(36 \%)$ and $6(24 \%)$ of cooking butter samples were graded as good, fair and poor, respectively, while $3(12 \%)$ samples of pasteurized butter were excellent ; $16(64 \%)$ good ; $4(16 \%)$ fair and $2(8 \%)$ of poor quality. Cooking butter samples showed average fat $\%$, acid degree value (ADV), iodine value, solid not fat (SNF) and moisture content as $76.27 \pm 5.17 ; 2.51 \pm 1.8 ; 36.29 \pm 16.7 ; 2.88$ +1.65 and $17.55 \pm 2.34$, respectively. While corresponding results for pasteurized butter were $81.66 \pm 5.96 ; 0.96 \pm 0.54 ; 43.07 \pm 11.9 ; 2.25 \pm 1.12$ and $15.07 \pm 2.09$, respectively. Nine $(36 \%)$ samples of cooking butter and $4(16 \%)$ samples of pasteurized butter had a fat content lower than the legal limit set by the Egyptian Standards not less than 78\% (EOSQC 154-5/2005). According to the results of Acid degree value (ADV) $2(8 \%)$ of cooking butter samples graded as normal $\{<0.4\} ; 5(20 \%)$ borderline $\{0.7-1.1\} ; 2(8 \%)$ slightly lipolyzed $\{1.2-1.5\}$ and 16 $(64 \%)$ were extremely lipolyzed $\{\geq 1.5\}$. Regarding pasteurized butter samples 11 (44\%) were normal ; $8(32 \%)$ borderline ; only one (4\%) were slightly lipolyzed and $5(20 \%)$ were extremely lipolyzed, while the legal limit set by the Egyptian Standards not exceed than $0.4 \%$ (EOSQC 154-5/2005). Measurement of iodine value (IV) declared that $20(80 \%)$ and $21(84 \%)$ of cooking and pasteurized butter samples, respectively were within the normal iodine value range (26-43). While 3 $(12 \%)$ and $4(16 \%)$ of cooking and pasteurized butter samples, respectively had higher values than the maximum limit and they may be adulterated by vegetable oils. Two (8\%) of cooking butter samples showed results lower than the minimum limit of iodine value. According to the results of Solid Not Fat (SNF), 12 (48\%) and $16(64 \%)$ of cooking and pasteurized butter samples, respectively were within the normal. While, $11(44 \%)$ and $5(20 \%)$ of cooking and pasteurized butter samples, respectively had high (SNF) content more than 3\%. Measurement of moisture content declared that $22(88 \%)$ and $23(92 \%)$ of cooking and pasteurized butter samples, respectively were in the normal limit, while $3(12 \%)$ and $2(8 \%)$ of cooking and pasteurized butter samples, respectively had moisture content higher than $18 \%$. All the examined butter samples were proved to be free from adulteration by starch.

Key words: Cooking, Pasteurized butter, acid degree value, iodine value, fat percent.

\section{INTRODUCTION}

Butter is a dairy product made by churning fresh or fermented cream or milk. It is generally used as a spread and a condiment, as well as in cooking, such as baking, sauce making and pan frying. Butter consists of butter fat, milk proteins and water (Ragheb et al., 2003 and Siddique et al., 2011).

Butter is a smooth fatty product made from milk, cream or both, with or without addition of common salt. It contains not less than $78 \%$ milk fat, not more than $18 \%$ water and in salted one, $1.5-2 \% \mathrm{NaCl}$. In addition, it may also contain lactic and flavor producing starter microorganisms (Lampert, 1975; Varnam and Sutherland, 1994). It has a very desirable flavor, it is perceived by consumers as high quality natural product and plays a prominent role in the cooking of many countries (Kaylegian, 1999; Fahmy and Abdel- Fattah, 2008).

Dairy products are often pasteurized during production to kill pathogenic bacteria and other 
microbes. Butter made from pasteurized fresh cream is called pasteurized butter. Production of pasteurized butter first became common in the $19^{\text {th }}$ century, with the development of refrigeration and the mechanical cream separator (Parfitt, 1934 ; Deeth and FitzGerald, 1976 ; Juffs and Deeth, 2007 ; Scutte, 2013).

Butter made from fresh or cultured unpasteurized cream called cooking butter. While butter made from pasteurized cream may keep for several months, cooking butter has a shelf life of roughly 10 days at $4^{\circ}$ C (ICMSF, 2005 ; Al-Hawary et al., 2012 ; Yasin and Shalaby, 2013).

Regarding nutritional value, butter is not only an important source of milk fat (16\% of total fat intake) and supply the body with $24 \%$ of saturated fatty acids (SFA) and 13\% mono unsaturated fatty acids and dietary energy but also source of fat soluble vitamins especially A and D (Hui, 1993; Varnam and Sutherland, 1994 ; Staessen et al., 1998 ; Wahba, 2003 ; Willson, 2013). In addition to vitamins A and $\mathrm{E}$, butter is a very rich source of selenium, which are vital antioxidants.

Actually butter contains many nutrients that protect against heart disease and cancer. In addition, it is rich in short and medium chain fatty acids and conjugated linoleic acid which gives excellent protection against cancer. Cholesterol found in butter fat plays an important role in the development of brain and nervous system in children, (Alfin-Slater and Aftergood, 1980).

Cooking butter is one of the most popular dairy products in Egypt, always made from sour cream which obtained by gravity, hence it well gain an acid taste. It is produced in villages by rural women that are usually using their traditional knowledge during manufacturing. It is eaten as butter, used as oil for food preparation or for cooking and also used as hairdressing and as a skin cosmetic by both sexes (Ahmed et al., 1987 ; Abdou, 2002 ; Fatouha et al., 2005 and Meshref, 2010).

According to the Egyptian Standards (EOSQC 154$5 / 2005$ ), cooking butter should have a minimum milk fat content of $78 \%$, maximum water content $18 \%$ (salted butter) and 20\% (if unsalted), while SNF, salt and acidity content must not exceed $3 \%, 2 \%$ and $10 \%$, respectively. Iodine value ranges from 26.4 43.1. In addition to, the product must be free from rancidity, foreign fat, residues, preservatives and thickeners (E. O. S. Q.C., 2005).

The iodine value (IV) gives a measure of the average degree of unsaturation of lipids, the higher the IV the greater the number of double bonds, consequently it can be used as an estimate of oxidative stability of lipids. Butter has low IV so it is less liable to oxidation. While acid degree value (ADV) is a good measure for the breakdown of the triacyl- glycerols into free fatty acids which have an adverse effect on the quality of fats (Sobeih, 2005 ; Abdelfattah and Saleh, 2007 ; Siddique et al., 2011).

This study was planned to throw light on the sensory (organoleptic) and physicochemical characteristics of locally manufactured cooked and pasteurized butter available in Alexandria city markets.

\section{MATERIALS and METHODS}

Collection of samples: Fifty random samples of cooking and pasteurized cow butter (25 samples each) at the point of consumption were randomly collected from retail and markets in Alexandria city. Samples were transferred to the laboratory directly with a minimum of delay for sensory and physicochemical examinations.

\section{Sensory (Organoleptical) evaluation:}

It was carried out according to the American Dairy Science association "ADSA" (1990). Scoring guide using 25 point system with 10 points for flavor ; 5 for body and texture ; 5 for color and appearance ; 3 for salt and 2 for the package was used. Sensory evaluation was done by 5 staff members of Food Hygiene Department. Total score of $\geq 90 \%$ was graded excellent or grade A ; 80-89\% good or B ; 60$79 \%$ fair or C $\leq 55 \%$ poor or grade D. (Guide for sensory evaluation of foods, 1971 and Larmond, 1977).

\section{Physicochemical evaluation: \\ - Compositional analysis:}

Determination of fat content by Roese Gottlieb method using ether extraction according to (Richardson, 1985).

\section{- Acid degree value (ADV):} used to measure free fatty acids (FFA) in the fat extract according to Richardson, (1985). The extent of hydrolytic rancidity in butter samples was discussed according to the suggested evaluation of ADV.

\section{- Determination of Iodine value:}

The method recommended by (Varnam and Sutherland, 1994).

\section{- Determination of total solids not fat:}

The method recommended by (AOAC, 1996).

\section{- Determination of moisture content:}

The method recommended by (AOAC, 2005). 


\section{- Detection of adulteration by starch:}

Butter may be adulterated with thickeners as starch so butter samples were examined for starch according to the method adapted by (Williams, 1972).
- Statistical analysis:

The obtained data was analyzed statistically according to (Perrie and Waston, 1999). The results are presented as the mean of three replicates. The analytical test used included unpaired Student t-test to compare means for two groups at $\mathrm{p}<0.05$.

\section{RESULTS}

Table 1: Sensory evaluation of the examined butter samples.

\begin{tabular}{|c|c|c|c|c|}
\hline \multirow[t]{2}{*}{ *Grade (Score) } & \multicolumn{2}{|c|}{$\begin{array}{c}\text { Cooking butter } \\
\qquad \mathbf{n}=25\end{array}$} & \multicolumn{2}{|c|}{$\begin{array}{c}\text { Pasteurized butter } \\
\mathrm{n}=\mathbf{2 5}\end{array}$} \\
\hline & No. of samples & $(\%)$ & No. of samples & $(\%)$ \\
\hline A "excellent" ( $\geq 90 \%)$ & 0 & 0 & 3 & $(12 \%)$ \\
\hline$B$ "good" (80-89\%) & 10 & $(40 \%)$ & 16 & $(64 \%)$ \\
\hline $\mathrm{C}$ "fair" (60- 79\%) & 9 & $(36 \%)$ & 4 & $(16 \%)$ \\
\hline D "poor" $(\leq 59 \%)$ & 6 & $(24 \%)$ & 2 & $(8 \%)$ \\
\hline
\end{tabular}

*According to Guide for sensory evaluation foods (1971) and ADSA (1990).

Table 2: Statistical analytical results of physicochemical character of the examined butter samples.

\begin{tabular}{|c|c|c|}
\hline Analytical value & $\begin{array}{c}\text { Cooking butter } \\
\qquad \mathbf{n}=25\end{array}$ & $\begin{array}{c}\text { Pasteurized butter } \\
\qquad \mathrm{n}=\mathbf{2 5}\end{array}$ \\
\hline & Mean \pm SD & Mean \pm SD \\
\hline Fat $\%$ & $76.27 \pm 5.17$ & $81.66 \pm 5.96$ \\
\hline ADV & $2.51 \pm 1.80$ & $0.96 \pm 0.54$ \\
\hline Iodine Value & $36.29 \pm 16.70$ & $43.07 \pm 11.9$ \\
\hline SNF & $2.88 \pm 1.65$ & $2.25 \pm 1.12$ \\
\hline Moisture content & $17.55 \pm 2.34$ & $15.07 \pm 2.09$ \\
\hline
\end{tabular}

$\mathrm{ADV}=$ Acid Degree Value

$\mathrm{SNF}=$ Solid Not Fat

Table 3: Frequency distribution of fat content in the examined butter samples.

\begin{tabular}{ccccc} 
& \multicolumn{2}{c}{ Cooking butter } & \multicolumn{2}{c}{ Pasteurized butter } \\
$\mathbf{n = 2 5}$ & \multicolumn{2}{c}{ Fat \% } & \multicolumn{2}{c}{ (\%) } \\
\cline { 2 - 5 } & No. of .samples & $(\%)$ & No. of samples & $(\%)$ \\
\hline$<\mathbf{7 8 \%}$ & 9 & $(36 \%)$ & 4 & $(16 \%)$ \\
\hline $\mathbf{7 8 - 8 0 \%}$ & 11 & $(44 \%)$ & 5 & $(20 \%)$ \\
\hline$>\mathbf{8 0} \%$ & 5 & $(20 \%)$ & 16 & $(64 \%)$ \\
\hline
\end{tabular}

Limits not less than $78 \%$ fat in E.O.S.Q.C. for natural butter (No. 154-5/2005) 
Table 4: Frequency distribution of acid degree value in the examined butter samples.

\begin{tabular}{cccccc}
\hline & & \multicolumn{2}{c}{ Cooking butter } & \multicolumn{2}{c}{ Pasteurized butter } \\
ADV & Degree of lipolysis & \multicolumn{2}{c}{ N=25 } & \multicolumn{2}{c}{ n=25 } \\
\cline { 3 - 6 } & & No. of samples & $(\%)$ & No. of samples & $(\%)$ \\
\hline$<\mathbf{0 . 4}$ & Normal & 2 & $(8 \%)$ & 11 & $(44 \%)$ \\
\hline $\mathbf{0 . 7 - 1 . 1}$ & Border line & 5 & $(20 \%)$ & 8 & $(32 \%)$ \\
\hline $\mathbf{1 . 2 - 1 . 5}$ & Slight lipolysis & 2 & $(8 \%)$ & 1 & $(4 \%)$ \\
\hline $\mathbf{1} 1.5$ & Unsatisfactory & 16 & $(64 \%)$ & 5 & $(20 \%)$ \\
\hline
\end{tabular}

Limits not exceed 0.4\% ADV in E.O.S.Q.C. for natural butter (No. 154-5/2005)

Table 5: Frequency distribution of Iodine value in the examined butter samples.

\begin{tabular}{ccccc}
\hline & \multicolumn{2}{c}{ Cooking butter } & \multicolumn{2}{c}{ Pasteurized butter } \\
Iodine value & \multicolumn{2}{c}{$\mathbf{n = 2 5}$} & No. of samples & $(\%)$ \\
\cline { 2 - 5 } & No. of samples & $(\%)$ & 0 & 0 \\
\hline $\mathbf{2 6}$ & 2 & $(8 \%)$ & 21 & $(84 \%)$ \\
\hline$>\mathbf{2 6}$ & 20 & $(80 \%)$ & $(16 \%)$ \\
\hline
\end{tabular}

Limits of Iodine Value range 26.4-43.1 in E.O.S.Q.C. for natural butter (No. 154-5/2005)

Table 6: Frequency distribution of solid not fat (SNF) content in the examined butter samples.

\begin{tabular}{ccccc}
\hline & \multicolumn{2}{c}{ Cooking butter } & \multicolumn{2}{c}{ pasteurized butter } \\
SNF \% & \multicolumn{2}{c}{$\mathbf{n = 2 5}$} & No. of samples & $(\%)$ \\
\cline { 2 - 5 } & No. of samples & $(\%)$ & 4 & $(16 \%)$ \\
\hline $\mathbf{2}$ & 2 & $(8 \%)$ & 16 & $(64 \%)$ \\
\hline$>3$ & 12 & $(48 \%)$ & 5 & $(20 \%)$ \\
\hline
\end{tabular}

Limits not exceed 3\% SNF in E.O.S.Q.C. for natural butter (No. 154-5/2005)

Table 7: Frequency distribution of Moisture content in the examined butter samples.

\begin{tabular}{ccccc}
\hline & \multicolumn{2}{c}{ Cooking butter } & \multicolumn{2}{c}{ pasteurized butter } \\
Moisture \% & \multicolumn{2}{c}{$\mathbf{n = 2 5}$} & \multicolumn{2}{c}{ n=25 } \\
\cline { 2 - 5 } & No. of samples & $(\%)$ & No. of samples & $(\%)$ \\
\hline$<\mathbf{1 5}$ & 4 & $(16 \%)$ & 7 & $(28 \%)$ \\
\hline $\mathbf{1 5 - 1 8}$ & 18 & $(72 \%)$ & 16 & $(64 \%)$ \\
\hline$>\mathbf{1 8}$ & 3 & $(12 \%)$ & 2 & $(8 \%)$ \\
\hline
\end{tabular}

Limits not exceed $18 \%$ moisture in E.O.S.Q.C. for natural butter (No. 154-5/2005)

** All the examined cooking and imported butter samples were free from starch. 


\section{DISCUSSION}

According to the Egyptian Standards (E.O.S.Q.C. 154-5/2005), cooking cow butter should have a minimum milk fat content of $78 \%$, maximum water content 18\% (salted butter) and 20\% (if unsalted), while SNF, salt and acidity content must not exceed 3,2 and $10 \%$ respectively. Iodine value ranges from 26.4-43.1 and ADV must not exceed than $0.4 \%$. In addition to, the product must be free from rancidity, foreign fat, residues, preservatives and thickeners (E. O. S. Q.C., 2005).

Results recorded in Table 1 show that 10 (40\%); 9 $(36 \%)$ and $6(24 \%)$ of the examined cooking butter samples were graded as good, fair and poor, respectively according to their sensory evaluation score while pasteurized butter recorded $3(12 \%)$ as excellent ; $16(64 \%)$ as good ; $4(16 \%)$ as fair and only $2(8 \%)$ were of poor quality.

Cooking butter samples are sold unpackaged so their appearance were unacceptable and some were unclean, but they were acceptable in terms of their taste, aroma and texture. Abdou (2002) recorded nearly similar results, he recorded 8.5 average score for flavor out of 10 points; 2.5 for body and texture out of 5 points ; 3.6 out of 5 for color and appearance ; 2.8 of 3 for salt while zero out of 2 point for package.

Regarding pasteurized butter organoleptic quality was satisfactory except some samples had very dry body and unnatural high color. Abdalla and Darwish (1998); Ahmed et al. (2013) reported that physicochemical characters of the examined pasteurized butter oil brands were highly acceptable in terms of their appearance, aroma, texture and taste.

In the present study, the cooking butter samples which obtained the lowest score for color had a high moisture content and that might be attributed to dispersion of large air cells in the butter samples. These finding were supported by (Ahmed, 2007 and FAO, 2010) that color of the butter is affected by high moisture content, presence of salt, large size of air cells and their dispersion in the butter fat granules.

The results of the present work was confirmed by (Douglas, 2006) who concluded that butter which had good fat percentage, moisture percentage, solids, solids not fat, color, texture and taste would give good appearance.

Larmond (1977); Rodriguez et al. (2003); ILS (2007) contributed that aroma is attributed to the presence of volatile acids. These findings were further supported by (Wright et al., 2001) who reported that butter flavor loss is due to inter-esterification at high temperature.

The findings of the present study showed that butter sample which achieved good texture scores get good taste scores. These results are supported by the conclusion of (Bornaz et al. (1995) who indicated that taste is attributed to the texture of the butter and how it taste in the mouth.

The finding of the butter texture scores might be due to the low iodine value in the range of $25-27$, as low iodine value attributed to less oxidation and good texture. These findings are also supported by facts given by Bornaz et al. (1995) who concluded that butter texture was dependent upon the low iodine value (25-27). Moreover, the butter with good fat content gives good texture scores. This result is also supported by Winton and Winton (2006) that fatty acids content of butter affect the texture of butter samples and $80 \%$ variation in texture is attributed to fatty acids, which gives desirable texture (Larmond, 1977; Neupaney et al., 2003; Samet-Bali et al., 2010).

Cooking and pasteurized butter samples recorded average fat contents of $76.27 \pm 5.17$ and $81.66 \pm 5.96$, respectively Table 2 . According to the E.S $36 \%$ and $16 \%$ of cooking and pasteurized butter samples, respectively didn't satisfy the standard fat content Table 3.

Nearly similar results were reported by Simpfendrfer and Cardoso (1989) as 65\% of samples were within the legal limit of minimum $80 \%$ fat. While Nazem (1991) found $16 \%$ of cooking butter samples had lower fat content than the Egyptian Standards, 2005.

On the other hand, $5(20 \%)$ and $16(64 \%)$ of the examined cooking and pasteurized butter samples, respectively had $>80 \%$ fat content Table 3 , Nambiar and Subrahmanyam (1975) found that 20 samples out of $70(28.6 \%)$ had milk fat of $>80 \%$. Lower results were reported by Hayaloglu and konar (2001) and Abdou (2002), as all their examined butter samples were below the minimum fat percent. While, higher results were recorded by Hankin and Hanna (1983) and EL- Demerdash (1990).

The low fat content in the examined cooking butter samples in the present study may be due to failure in working (under working) which results in high moisture and low fat content or due to adulteration by adding thickeners other than starch.

Nadeem et al. (2012) reported that the highest butter fat content $(89 \%)$ was achieved by using cream of $35 \%$ fat and churning the samples at $10^{\circ} \mathrm{C}$ temperature. The present study shows increasing trend in the butter yield with decreased temperature; this might be due to the reason that low temperature 
of churning leads to rapid fat coagulation and large butter granules which have more fat content. These findings are supported by Sun et al. (2008) who reported that low temperature churning gives rapid coagulation of butter fat.

The ADV in cooking butter samples recorded average value of $2.51 \pm 1.8$, while it was $0.96 \pm 0.54$ for pasteurized butter samples Table 2. Regarding the degree of lipolysis, $16(64 \%)$ and $5(20 \%)$ of the examined cooking and pasteurized butter samples, respectively were unsatisfactory (Table 4), which indicates that these samples are undergo hydrolytic rancidity either due to the initial high lipase enzyme in milk or cream used for butter manufacture or more likely due to contamination with lipolytic microorganisms. The results revealed that, only 2 $(8 \%)$ of the examined cooking butter samples were normal ( $<0.4 \mathrm{ADV}), 5(20 \%)$ were borderline (1.2-1.5 ADV), while $16(64 \%)$ were extremely lipolyized $(\geq$ 1.5 ADV), Table 4.

High acidity level were also recorded by Nambiar and Subrahmanyam (1975). Also, Nazem (1991) recorded that 60 and $64 \%$ of the examined cooking and pasteurized butter samples exceeded the acidity limits specified by the Egyptian Standards, 2005. While Hatipoglu (1972) recorded only 3(7.7\%) rancid butter samples examined in Turkey. Augusta and Santana (1998) and Abdou (2002) found the acidity of all butter samples were in the expected range.

A declining trend in free fatty acids with decrease in temperature might be attributed to the finding of Hunziker (1948) who reported that free fatty acids value increased during churning and reduced with decrease in temperature. High fat content gives rise to more free fatty acids content, so the increase in the fat percentage of churned cream leads to increase in the free fatty acids in the end product. These findings agreed with the findings of Sawaya et al. (1984) ; AlKhalifa and Al-khatani (1993); Walstra et al. (1999) who concluded that the high fat cream churning gives rise to more free fatty acids content. The present results is also confirmed by Uphus (1996) who found that free fatty acids in sweet cream butter samples ranged between 0.3 to $0.6 \%$.

In some instances, butter manufacturer replace milk fat by cheaper fats as vegetable fat, this adulteration could be detected by determination of iodine value (IV). Milk fat butter has low IV while vegetable oils have high IV due to greater number of unsaturated fatty acids.

The mean of iodine value were $36.29 \pm 16.7$ and $43.07 \pm 11.9$ for cooking and pasteurized butter samples, respectively as recorded in Table 2 . The IV exceeded the normal limit (26-43) in $3(12 \%)$ and 4
$(16 \%)$ of the examined cooking and pasteurized butter samples, respectively Table 5 . Twenty $(80 \%)$ cooking butter samples were within the normal limit, while two (8\%) samples recorded IV lower than the minimum limit. Regarding pasteurized butter samples, $21(84 \%)$ samples were within the normal limit Table 5.

Similar results were recorded by Augusto and Santana (1998), who recorded that $15.2 \%$ of samples exceeded the legal limit for IV. While Hatipoglu (1972) recorded nearly normal IV range (24.3- 44) with an average of 33.6. Also Downey (1975) recorded IV range of 29-35 for both slightly salted ripened cream butter and salted sweet cream butter samples manufactured in Ireland.

The mean solid not fat (SNF) were $2.88 \pm 1.65$ and $2.25 \pm 1.12$ for cooking and pasteurized butter samples, respectively as recorded in Table 2 . The SNF exceeded the normal limit 3\% in $11(44 \%)$ and 5 $(20 \%)$ of the examined cooking and pasteurized butter samples, respectively (Table 6). 12 (48\%) cooking butter samples were within the normal limit, while $2(8 \%)$ samples recorded SNF lower than $2 \%$. Regarding pasteurized butter 16 (64\%) samples were within the normal limit Table 6 . Lower results were recorded by Keogh (2006) who reported that SNF in butter samples would be up to $2 \%$.

The results of the present study for solids not fat could be attributed to the butter texture containing large and good structure fat globules had fewer amounts of other solids. The findings of the study were supported by Walstra et al. (1999) who stated that the solids not fat are the amount of solids present in butter fat globule except fat.

The mean moisture content were $17.55 \pm 2.34$ and $15.07 \pm 2.09$ for cooking and pasteurized butter samples, respectively as recorded in Table 2 . The moisture content exceeded the normal limit $18 \%$ in 3 $(12 \%)$ and $2(8 \%)$ of the cooking and pasteurized butter samples, respectively Table 7.18 (72\%) cooking butter samples were within the normal limit, while $4(16 \%)$ samples recorded a moisture content lower than $15 \%$. While pasteurized butter samples 16 (64\%) samples were within the normal limit, 7 (28\%) samples recorded a moisture content lower than $15 \%$.

In the present study while observing moisture content with respect to butter fat levels, the highest moisture content might be due to the increase in free fatty acids. These findings are supported by Sağdic et al. (2004) and Funahashia and Horiuchi (2008) reported that the increase in free fatty acids is due to the churning which influence the moisture content. Churning at low temperature resulted in low moisture content due to the formation of large butter globules 
with good drainage of butter milk. The more pronounced change in moisture $\%$ might be due to the significant change in fat level of butter samples Walstra et al. (1999).

In the current study all the fifty cooking and pasteurized butter samples were proved to be free from adulteration by starch. However, GarciaOlmedo and Gastanaduy (1971) and Singh et al. (1975) found that $51.2 \%$ and $16 \%$ of the examined butter samples in madrid and India, respectively were adulterated by starch.

\section{REFERENCES}

Abdalla, A.E.M. and Darwish, S.M. (1998): Characteristics of some imported and local butter oils. Alex. J. of Agric. Res., 40 (1): 159-168.

Abdelfattah, M.E. and Saleh, M.A. (2007): Quality evaluation of butter marketed at Sharkia Governorate. $5^{\text {th }}$ Int. Sci. Conf., Mansoura.1011 April 2007.

Abdou, A.M. (2002): Quality evaluation of cooking butter sold at some collecting centers in Kaliobyia Governorate. Benha Vet. Med. J., 13 (1): 24-36.

Ahmed, A.A-H.; Moustafa, M.K. and Abdel-Hakiem, E.H. (1987): Sanitary condition of cooking butter manufactured in Assiut city. Ass. Vet. Med. J., 17 (37): 82-87.

Ahmed, A. (2007): Chemistry of food colors. Submitted by Kiran naz, Food chemistry 07arid-64 FT, $6^{\text {th }}$ semester 1-43.

Ahmed, S.; Anjum, F.M.; Huma, N.; Sameen, A. and Zahoor, T. (2013): Composition and physicochemical characteristics of buffalo milk with particular emphasis on lipids, proteins, minerals, enzymes and vitamins. Animal and plant science J., 23(1):62-74, ISSN:1018-7081.

Alfin-Slater, R.B. and Aftergood, L. (1980): "Lipids" Modern Nutrition in Health and Disease. Chapter 5, $6^{\text {th }}$ ed. R.S. Goodhart and M.E. Shils eds, Lea and Febiger Philadelphia 1980. P.131.

Al-Hawary, I.I.; Al-Ashmawy, M.A.M.; Algazar, M.M. and Zahran, A.M.M. (2012): Studies on lipolytic bacterial contamination in butter. $7^{\text {th }}$ Int. Sci. Conf., Mansoura 28-30 August 2012.

Al-Khalifa, A. and Al-Khatani, S. (1993):Composition of ghee (Samn Barri) from cow's and sheep's milk. Food chemistry J., 46:373-375.

ADSA (American Dairy Science Association) (1990): Dairy science and Technology Handbook. 1principles and properties, VCH publisher Inc. New York, 10010X.

AOAC (Association of official Analytical chemists), (1996): Official methods of analysis.
Association of Official Analytical Chemists, Virginia, 22201, Arlington.

AOAC (Association of official Analytical chemists), (2005): Official methods of analysis. $16^{\text {th }}$ ed. Washington, DC, USA, PP. 20-49.

Augusta, I.M. and Santana, D.M.N.(1998): Quality evaluation of commercial butters in Rio de Janeiro state. Cienciae Technologia de Alimentos, 18 (4): 377-381.

Bornaz, S.; Fanni, J. and Parmentier, M. (1995): Heat-treatment of cream: A model of the butter texture response in relation with triglyceride composition. J. Am. Oil Chem. Soc., 72: 163.

Deeth, H.C. and Fitz-Gerald, C.H. (1976): Lipolysis in dairy products: A review. Australlian J., Dairy Technology, 31:53-64. Doi:1016/J. dairy -2004.01.005.

Douglas, G. (2006): Butter Manufacture. Dairy Science and Technology Education, University of Guelph, Canada.

Downey, W.K. (1975): Butter quality. Dairy Res. Rev. series, An Foras Taluntais. No. 7,142.

E.O.S.Q.C. (Egyptian Organization for Standardization and Quality control), (2005): Standard for native cow's butter.154-5/2005.

El-Demerdash, M.S. (1990): Chemical and bacteriological studies on some local and imported dairy products. M.V.SC. Thesis, Fac. Agric., Zagazig Univ.

Fahmy, B.G. and Abdel-Fattah, S.A. (2008): Mycological and heavy metals incidence in butter with a trial of these metals elimination. J. Egypt Vet. Med. Assoc., 68(2): 197-188.

FAO (Food and Agriculture Organization), (2010): Highlights of the OECD-FAO outlook 19702017.Website:http://www.stats.oecd.org/Index .aspx? Data Set Code=HIGH_AGLINK_ Accessed on 23 August.

Funahashia, H. and Horiuchi, J. (2008): Characteristics of the churning process in continuous butter manufacture and modeling using an artificial neural network. Int. Dairy J.,18: 323-328.

Fatouha, A.E.; Singhb, R.K.; Koehlerb, P.E.; Mahrana, G.A. and Metwallya, A.E. (2005): Physical, chemical and stability properties of buffalo butter oil fractions obtained by multistep dry fractionation Food chemistry J., 89(2): 243-252.

Garcia-Olmedo, $R$. and Gastanaduy, M. del $C$. (1971): Spanish butter: Commercial butter. Anales de Bromatologia, 23 (4): 387-402.

Guide for sensory evaluation of foods (1971): Part I and II, IS: 6273-1.Manak Bhavan, 9 Bahadur shah zafar Marg, New Delhi, 110002, India.

Hankin, L. and Hanna, J.G. (1983): Quality of butter and blends of butter with oleomargarine Dairy and food Sanitation 3 (12): 458-460. 
Hatipoglu, M. (1972): Chemical investigations on butters collected from different regions of Turkey. Etlik, Vet. Bakteriyoloji Enstitusu. Dergisi, 4 (1/2 ): 63-74.

Hayaloglu, A.A. and Konar, A. (2001): A comparative study on physicochemical and sensorial properties of butter made from yogurt and cream. Milchwissenschaft, 56 (12): 675-677.

Hui, Y.H. (1993): Dairy science and TechnologyHand book, Vol. 2. Product manufacturing VCH, USA.

Hunziker, O.F. (1948): The physical aspects of butter. Milchwissenschaft Milk Sci. Int. 3(3): 75-82.

ICMSF (International Committee on Microbiological Specifications for Food), (2005): Microorganisms in foods $1^{\text {st }}$-Theirsignificance and methods of enumeration $2^{\text {nd }}$. Ed. Univ. of Toronto Press, Toronto Buffalo and London.

ILS (Integrated Laboratory Systems), (2007): Research Triangle Park, NC. Chemical information Review Document for Artificial Butter flavoring and constituents Diacetyle and Aceton. U.S. Department of Health and Human services, under contract No.1-Es35515.

Juffs, H. and Deeth, H. (2007): Scientific evaluation of pasteurization for pathogen reduction in milk and milk products. Food standards Australia New Zealand 1-153 ISBN 978-0642-34 555-4.

Kaylegian, K.E. (1999): The production of specialty milk fat ingredients. J. Dairy Sci., 82(7):14331439.

Keogh, M.K. (2006): Chemistry and technology of butter and milk fat spreads. Adv. Dairy Chem. Lipids, 2: 333-363.

Lampert, L.M. (1975): Modern dairy products. $3^{\text {rd }}$ ed Chemical Publishing company, Inc. New York.

Larmond, E. (1977): Laboratory methods for sensory evaluation of foods. Ottawa. Canada. Dep. Agric. Pub. pp. 1637-1674.

Meshref, A.M.S. (2010): Microbiological Quality and safety of cooking butter in Beni-Suef governorate-Egypt. African Health Sciences, 10(2):193-198 and Cited in Assuit Vet. Med. J., 55(121): 143-153, 2009.

Nadeem, M.; Abdullah, M.; Javid, A.; Arif, A.M. and Mahmood, T. (2012): Evaluation of functional fat from interesterified blends of butter oil and Moringa Oleifera oil. Pakistan J. Nutrition, 11(9):725-729.

Nambiar, K.K.G. and Subrahmanyam, M. (1975): Studies on the quality of butter in Trichur Town. Kerala J. of Vet. Scie. 6 (1/2) 43-48.

Nazem, A.M. (1991): Assessment of the hygienic quality of some dairy products. Ph. D. Thesis, Fac. Vet. Med. Alex. Univ.
Neupaney, D.; Kim, Jin-bo.; Ishiorosh, M. and Samejima, K. (2003): Study on some functional and compositional properties of yak butter lipid. Animal Science J., 74(5): 391397.

Parfitt, E.H. (1934): Methods for the microbiological analysis of Butter. American J. Public Health and nations Health, 24(4):303-308.

Perrie, A. and Watson, L. (1999): Statistics in Veterinary and Animal's Science $1^{\text {st }}$ Ed. The Bark well Science Rd, UK.

Ragheb, R.R. and Nour, M.K. Hassan (2003): Studies on fungi in butter and margarine with special reference to the toxigenic strains. J. Egypt. Vet Med. Assoc., 63(1): 379-386.

Richardson, G.H. (1985): Standard methods for the examination of dairy products, $15^{\text {th }}$ ed. American Public Health Association, Washington, DC.

Rodriguez, A.; Bunger, A.; Castro, E.; Sousa, I. and Empis, J. (2003): Development and Optimization of Cultured Goat Cream Butter. J. Am. Oil Chem. Soc., 80(10): 987-992.

Sağdic, O.; Doznmez, M. and Demirći, M. (2004): Comparison of characteristics and fatty acid profiles of traditional Turkish yayik butters produced from goats, ewes or cow's milk. food control J., 15(6): 485-490.

Samet-Bali, O.; Ayadi, M.A. and Attia, H. (2010): Traditional Tunisian butter: Physicochemical and microbial characteristics and storage stability of the oil fraction. Int. J. of Dairy Technology, 63(1):77-85. Cited in LWT Food science and Technology J., 42(4):899-905, May 2009.

Sawaya, W.N.; Khan, P. and Shalhat, F.A. (1984): Physical and chemical characteristics of ghee and butter from goat's and sheep's milk. Food chemistry J., 14: 227-232.

Scutte, L.M. (2013): Isolation and identification of the microbial consortium present in fermented milks from Sub-Saharan. Africa Masters of sciences in food science, Department of food science, Faculty of Agrisciences stellen bosch university.

Siddique, F.; Khan, K.S.; Ahmed, A.; Gulfraz, M. and Wattoo, F.H. (2011): Development and optimization of sweet cream butter from buffaloes at cottage scale. African J. of Biotechnology, 10(75): 17265-74.

Simpfendrfer, R.S. and Cardoso, A.V. (1989): Chemical composition of artisan-made butter in the province of, Uble. Agro-Ciencia, 5 (2):15-18.

Singh, G.B.; Khanna, S.K. and Singh, S.B. (1975): Extent of adulteration in Vanaspati oils, ghee and butter. Oils and oilseeds J., 27 (7): 13-14.

Staessen, L.; Henauw, S.D.E.; Bacquer, D.D.E.; Backer, G.D.E.; Peteghem, C.V. (1998): Fat 
sources in the Belgian diet. Annals of Nutrition and Metabolism 42(3): 138-150 D.S.A, 60 (11) P. 863.

Sun, J.; Kitamura, Y. and Satake, T. (2008): Application of stirling cooler to food processing: feasibility study on butter churning. J. Food Eng., 84(1):21-27.

Uphus, A. (1996): Milk fat processing. Westphalia Separator Food Tech., GmbH. pp. 27.

Varnam, A.H. and Sutherland, J.P. (1994): Milk products-Technology, Chemistry and Microbiology $1^{\text {st }}$ ed. Chapter 6 , published by Chapman and Hall London, Glasgow, New York, Tokyo, Melbourne and Madras.

Wahba, N.M.M. (2003): Assessment of the mycological status of butter sold in Assuit Governorate. $2^{\text {nd }}$ Int. Cong. Of Food Hygiene and Human Health 21-23 October 2003.

Walstra, P.; Geurts, T.J.; Noomen, A.; Jellema, A. and Van Boekel, M.A.J.S. (1999): Dairy Technol., Marcel Dekker, Inc. New York, pp. 498.
Williams, H.A. (1972): J. of the Association of Public analysis, 10: 99 Cited after David, P. (1976), The chemical analysis of foods $7^{\text {th }}$ ed. Edinburgh, London and New York.

Willson, M. (2013): Characteristics and production of Vanaspati, Ghee, Butter and other solid fats. Lipologic Food Technology consultancy cary, North Carolina, USA. E mail: mwillson @)nc.rr.com.

Winton, A.L. and Winton, K.B. (2006): Milk and milk products. Agrobios, Jodhpur, India. p. 160.

Wright, A.J.; Scanlon, M.G.; Hartel, R.W. and Marangoni, A.G. (2001): Rheological properties of milk fat and butter. J. Food Sci. 66: 1056-1071.

Yasin, N.M.N. and Shalaby, S.M. (2013): Physicochemical and sensory properties of functional low fat cheese cake manufactured using cottage cheese. Annals of Agri Science, 58(1):61-67.
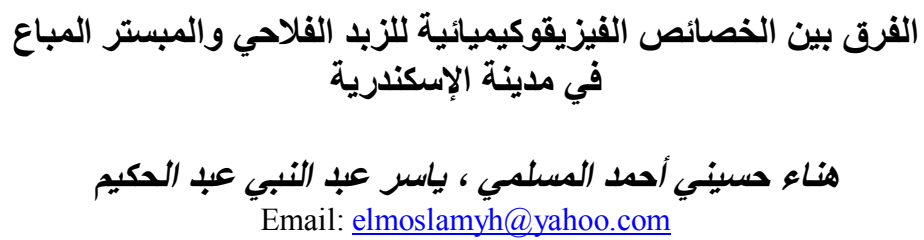

أجريت هذه الدر اسة لفحص خمسون عينة زبد بقري (0 إن عينة زبد فلاحي و 0ب عينه زبد مبستر) تم تجميعها من الأسو اق و السوبر

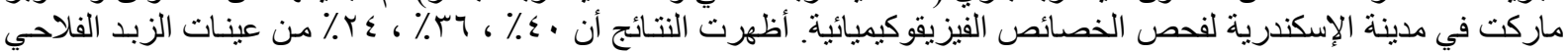

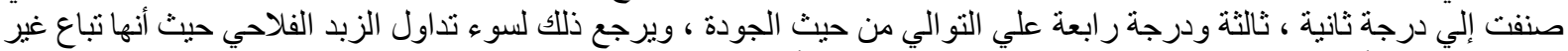

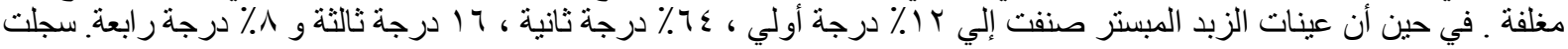

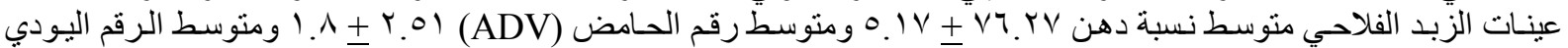

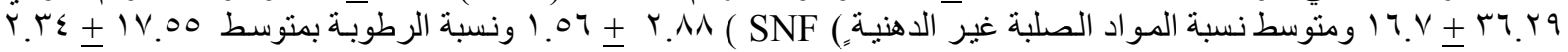

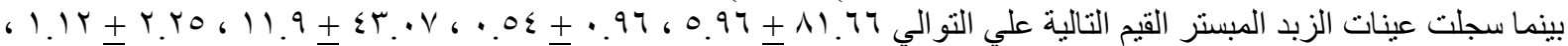

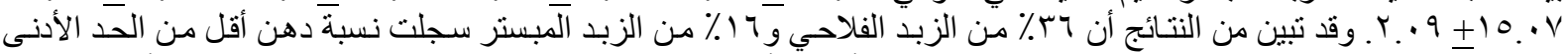

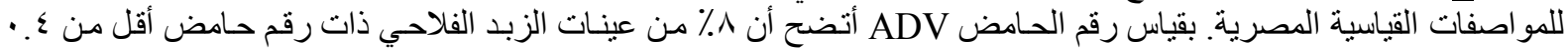

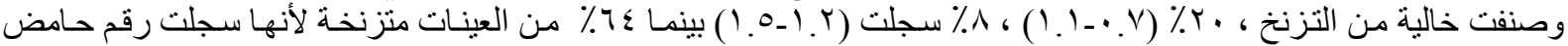

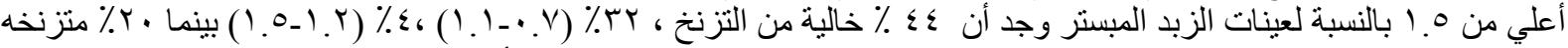

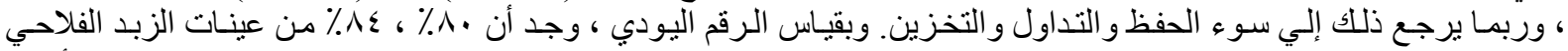

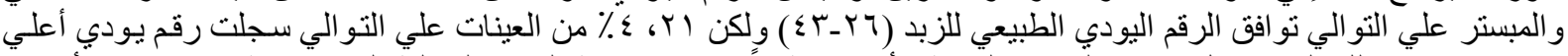

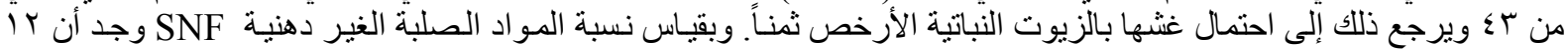

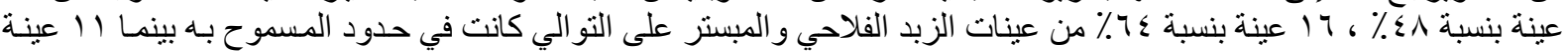

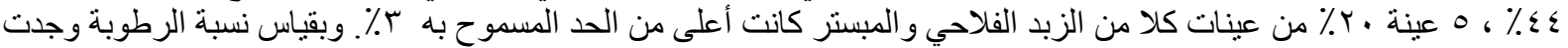

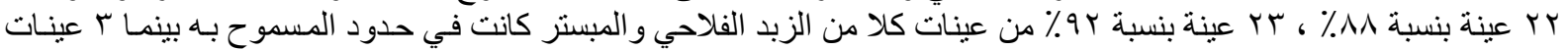

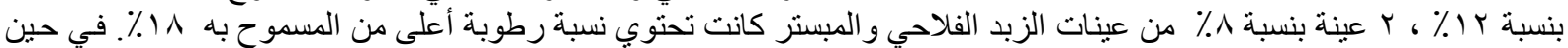
أن فحص العينات أنثبت خلو جميع العينات من من الغش بالنشا. 